\title{
Effects of Estuary-Wide Seagrass Loss on Fish Populations
}

\author{
Jennifer K. O'Leary ${ }^{1,2,3}$ (D) Maurice C. Goodman ${ }^{1,4} \cdot$ Ryan K. Walter $^{2} \cdot$ Karissa Willits $^{5} \cdot$ Daniel J. Pondella $^{6}$. \\ John Stephens ${ }^{6}$
}

\begin{abstract}
Globally, habitat loss in coastal marine systems is a major driver of species decline, and estuaries are particularly susceptible to loss. Along the United States Pacific coast, monospecific eelgrass (Zostera marina) beds form the major estuarine vegetated habitat. In Morro Bay, California, eelgrass experienced an unprecedented decline of $>95 \%$, from 139 ha in 2007 to $<6$ ha by 2017. Fish populations were compared before and after the eelgrass decline using trawl surveys. Beach seines surveys were also conducted during the post-decline period to characterize species within and outside of remnant eelgrass beds. While the estuarywide loss of eelgrass did not result in fewer fish or less biomass, it led to changes in species composition. The post-eelgrass decline period was characterized by increases in flatfish (mainly Citharichthys stigmaeus) and staghorn sculpin (Leptocottus armatus), and decreases in habitat specialists including bay pipefish (Syngnathus leptorhynchus) and shiner perch (Cymatogaster aggregata). There were similar trends inside and outside of remnant eelgrass patches. These findings support evidence across multiple ecosystems suggesting that the predominance of habitat-specialists predicts whether or not habitat loss leads to an overall decline in fish abundance. In addition, loss of critical habitats across seascapes can restrict population connectivity and lead to range contraction. For bay pipefish, the loss of eelgrass in Morro Bay is likely to create a population biogeographic divide. Currently, Morro Bay is dominated by flatfish and sculpins, and the longevity of this new ecosystem state will depend on future eelgrass recovery dynamics supported by ecosystem-based management approaches.
\end{abstract}

Keywords Habitat loss $\cdot$ Zostera marina $\cdot$ Species composition $\cdot$ Morro Bay $\cdot$ California

\section{Introduction}

Habitat loss has been a major driver of contemporary species declines in terrestrial ecosystems (Hoekstra et al. 2005; Fischer and Lindenmayer 2007) and is increasingly a driver of change in marine ecosystems (Pimm et al. 2014; McCauley et al. 2015). Until recently, population decline of marine fishes

Communicated by Nathan Waltham

Jennifer K. O’Leary

oleary.biology@gmail.com

1 California Sea Grant, La Jolla, CA, USA

2 California Polytechnic State University, San Luis Obispo, CA, USA

3 Wildlife Conservation Society, Mombasa, Kenya

4 Hopkins Marine Station, Stanford University, Pacific Grove, CA, USA

5 Morro Bay National Estuary Program, Morro Bay, CA, USA

6 Vantuna Research Group, Occidental College, Los Angeles, CA, USA was driven by overexploitation (Pauly et al. 2002; Myers and Worm 2003), but anthropogenic impacts are now modifying marine habitats across a range of spatial scales (Dulvy et al. 2003; Airoldi et al. 2008; Waycott et al. 2009; McClenachan et al. 2017; Hansen et al. 2019). Trends in ocean use and the exploitation of resources suggest that habitat destruction will become a dominant threat to marine habitats over the next century (McCauley et al. 2015). Loss of habitats can lead to shifts in ecosystem state resulting in losses of ecological and economic resources that may be difficult to reverse (e.g., kelp forests: Ling et al. 2015; seagrasses: Maxwell et al. 2017; coral reefs: Mumby et al. 2007; and theoretical: Scheffer et al. 2001). Along with a reduction of physical complexity, habitat loss can lead to the loss of resident species and reduced functional diversity (e.g., Myers et al. 2000). In marine ecosystems, connectivity is often driven by larval dispersal, and increasing habitat patchiness across marine coastlines may have major impacts on population dynamics at scales larger than the loss of any one habitat.

Estuarine ecosystems are especially susceptible to human impacts, such as overexploitation, pollution, eutrophication, and sea level rise (Nagelkerken et al. 2015; Elliott et al. 
2014; Wang et al. 2015; Lu et al. 2018). Historical and archeological data suggest that human impacts have destroyed $67-91 \%$ of estuarine habitats, and consequently, up to $80 \%$ of the associated fish and shellfish populations (Lotze et al. 2006; Jackson 2008). Seagrass meadows are one of the main habitats in estuaries and represent one of the most biologically productive biomes on earth (Duarte 2002). They provide nursery grounds and habitat for numerous fishes (Beck et al. 2001; Whitfield 2017; Lefcheck et al. 2019) and invertebrates (Beck et al. 2001) and ecosystem services including sediment and shoreline stabilization, water filtration, and carbon sequestration (Short and Wyllie-Echeverria 1996; Waycott et al. 2009; Walter et al. 2020). Faunal densities in seagrass meadows can be orders of magnitude above unvegetated areas (Hemminga and Duarte 2000). Yet, seagrasses are declining at an alarming rate, with loss rates that now rival those reported for tropical rainforests, coral reefs, and mangroves (Waycott et al. 2009; Krause-Jensen et al. 2020). Seagrass loss is largely attributed to anthropogenic impacts including pollution, eutrophication, sedimentation, fishing, dredging and alteration of shorelines, introduction of invasive species, and climate change (Short and Wyllie-Echeverria 1996; Duarte 2002; Orth et al. 2006; Krause-Jensen et al. 2020). Loss is usually the symptom of a larger stressor or problem, and seagrasses are therefore considered "coastal canaries," because their decline signals important losses to biodiversity and ecosystem services (Orth et al. 2006).

Along the Pacific Coast of the United States, the main seagrass species is an eelgrass, Zostera marina (Short et al. 2007). Zostera marina (hereafter eelgrass) forms monospecific stands in shallow coastal waters and estuaries. This lack of functional redundancy makes these meadows potentially less resilient to stressors (Waycott et al. 2009). Furthermore, along the Pacific Coast of the United States, eelgrass is relatively sparse: present in only $21 \%$ (24 of 110 ) of estuaries in Washington, Oregon, and northern California; 17\% (18 of 107) of estuaries in Central California; and 36\% (22 of 61) of estuaries in the Southern California Bight (Sherman and Debruyckere 2018). Compared to the Atlantic Coast of the United States, Pacific Coast estuaries are separated by large distances and represent a small proportion of coastal habitats (e.g., $20-25 \%$ of the Pacific Coast habitat versus $80-90 \%$ of the Atlantic and Gulf of Mexico habitat; Yoklavich et al. 1991). Where seagrass diversity is low or distribution is limited, loss is expected to have strong impacts on marine biodiversity and ecosystem health (Short et al. 2011). Species dependent on eelgrass habitat in estuaries along the Pacific coast likely have limited population connectivity and thus are particularly vulnerable to eelgrass loss.

In Morro Bay, a major estuary along the Central Coast of California, eelgrass has declined by more than $95 \%$ since 2007, going from 139 ha (344 acres) to less than 6 ha (15 acres) by 2017 (Fig. 1). Most loss occurred between 2007 and 2013, and the causes of the decline are not yet known. Environmental conditions in large portions of the back bay may be inhibiting widespread eelgrass recovery (Walter et al. 2018a), though there are recent signs of re-emergence. Morro Bay is one of the 28 estuaries designated by the EPA as "nationally significant estuaries" in the USA (under the National Estuary Program) deemed as critical to the economic wellbeing and environmental health of the nation. Given habitat loss encompassing an entire estuary, it is critical to evaluate how associated species have changed. Seagrass meadows typically harbor a diverse range of permanent and temporary fish residents of all age ranges (e.g., Nakamura and Tsuchiya 2008). Previous studies have indicated higher fish densities and species richness in seagrass than in unvegetated habitats, as well as substantial differences in the community composition of fish assemblages (Hughes et al. 2002; Heck et al. 2003; Airoldi et al. 2008; McCloskey and Unsworth 2015). However, there has not been an eelgrass decline on the United States Pacific Coast of this magnitude, making this a novel event that may help predict future estuarine change.

Estuary-wide fish populations were assessed prior to the eelgrass decline (2006-2007), and surveys were repeated after the decline (2016-2017). Since post-decline surveys did not cover any of the remnant eelgrass beds, beach seine surveys were conducted inside and outside of eelgrass habitat during the post-decline period. It was hypothesized that there would be declines in fish biomass, species richness, and diversity, and changes in species composition corresponding with the loss of eelgrass-dependent species.

\section{Methods}

\section{Study site and eelgrass decline}

Morro Bay is a shallow estuarine system located along the Central California Coast (USA). This seasonally lowinflow estuary (Walter et al. 2018a) is characterized by a narrow channel that gets increasingly shallower going from the mouth to the head. The intertidal and shallow subtidal regions of Morro Bay were historically dominated by eelgrass, with approximately 139 ha (344 acres) of intertidal eelgrass as recently as 2007 (Fig. 1). However, since 2007 , eelgrass has declined by more than $95 \%$ to less than 6 ha (15 acres) in 2017. The remaining eelgrass beds are mainly restricted to areas along the main channel near the mouth of the bay.

\section{Trawl surveys: before and after eelgrass declines}

Trawl surveys were conducted before (2006-2007) and after (2016-2017) the eelgrass decline at seven sites in Morro Bay (Fig. 1a) during high tide (Table 1). Four sites were surveyed 


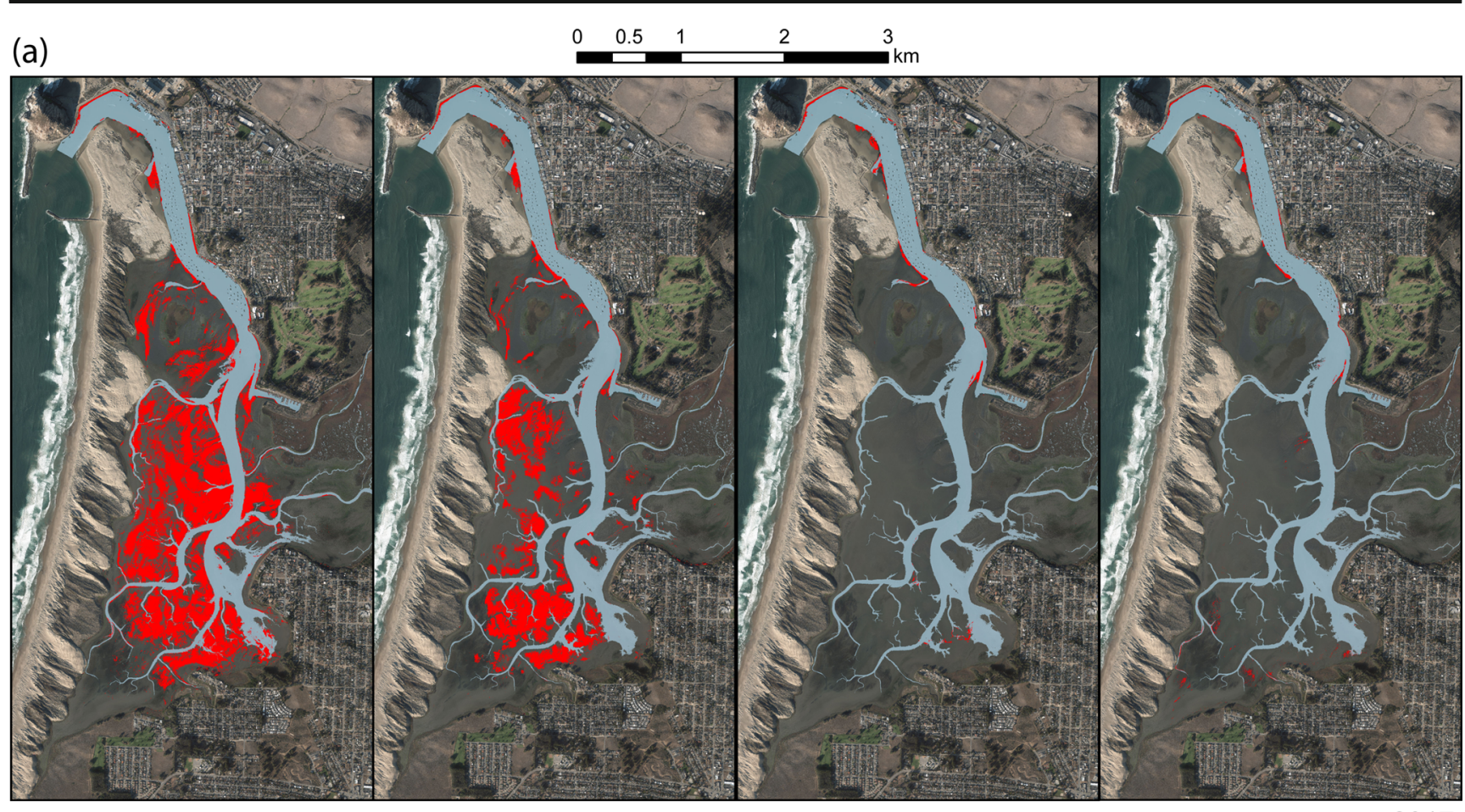

2007

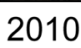

2013

2017

Eelgrass extent Subtidal channel

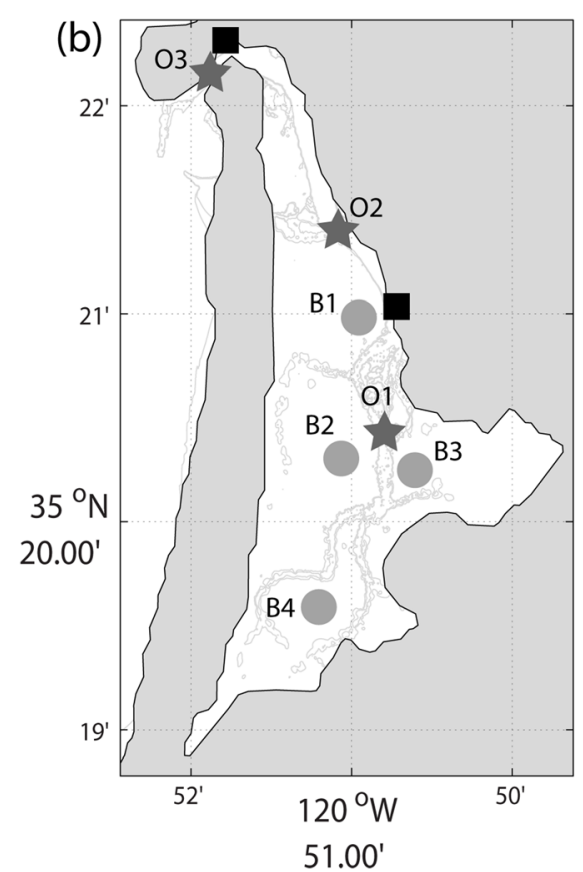

Intertidal beam trawl

Subtidal otter trawl

- Beach seine

Fig. 1 a Aerial maps of eelgrass density over time in Morro Bay, with eelgrass coverage indicated in red. b Map of beach seine and approximate trawl survey locations, with survey and gear type indicated by the shape of points

in the back-bay intertidal flats using a beam trawl (2 m wide at the mouth, $4 \mathrm{~m}$ long, with a 1-m reinforced cod end and a 4$\mathrm{mm}$ mesh size). The channel is dredged annually and is too deep for eelgrass to survive, but has persistent eelgrass along the margins. Thus, three sites in the channel were surveyed using an otter trawl ( $4.6 \mathrm{~m}$ wide at the mouth, $7.2 \mathrm{~m}$ long with a mesh size of $14 \mathrm{~mm}$ in the wings, and $8 \mathrm{~mm}$ in the cod end).
Temporal and seasonal changes are assessed independently for each trawl type.

All trawls (beam and otter) were 10-11 min long at a speed (over ground) of $0.8-1.8$ knots. Trawls were conducted during two seasons: October-November (fall) and June-August (summer). In the pre-decline period, three replicate trawls were conducted per site per season per year at each of six sites. 
Table 1 Summary of Morro Bay trawl samples used to compare fish populations in the pre- and post-eelgrass decline periods: by time period, habitat, and season. Mean tidal height $( \pm \mathrm{SD})$ is given as meters relative to mean lower low water (MLLW)

\begin{tabular}{lllllll}
\hline Period & Habitat & Season & Sites & Replicates & Mean depth* (m) & Mean tidal height (m) \\
\hline Post-decline & Intertidal flats & Fall & 3 & 10 & $1.1 \pm 0.2$ & $1.4 \pm 0.2$ \\
(2016-2017) & & Summer & 3 & 9 & $1 \pm 0.4$ & $0.7 \pm 0.3$ \\
& \multirow{2}{*}{ Channel } & Fall & 3 & 8 & $5.5 \pm 1.1$ & $1.2 \pm 0.2$ \\
& & Summer & 3 & 9 & $5.2 \pm 0.8$ & $1 \pm 0.2$ \\
Pre-decline & \multirow{2}{*}{ Intertidal flats } & Fall & 3 & 18 & 1 & $0.7 \pm 0.4$ \\
(2006-2007) & & Summer & 3 & 15 & $1.1 \pm 0.3$ & $1.1 \pm 0.2$ \\
& \multirow{2}{*}{ Channel } & Fall & 3 & 18 & $4.2 \pm 2.1$ & $0.9 \pm 0.2$ \\
& & Summer & 3 & 18 & $5 \pm 1.6$ & $1.1 \pm 0.1$ \\
\hline
\end{tabular}

*For pre-decline surveys, we report the mean depth and standard deviation for those surveys that had recorded depth ( $74 \%$ of surveys in this period had depth data)
In the intertidal flats during the pre-decline period, sites B1, B2, and B4 were consistently surveyed using a beam trawl except in the summer of 2006, when site B3 was surveyed instead of site B4 (Fig. 1b). In the post-decline period, two to four replicate trawls were conducted per site per year at seven sites (Fig. 1b), with surveys conducted in the fall of 2016 and the summer of 2017. At the end of each trawl (otter and beam), all organisms were removed from the trawl nets, fish were identified to species, and the total length of each fish was measured to the nearest $\mathrm{mm}$. Fish were returned alive to the water at their collection site.

\section{Beach seine surveys: eelgrass presence and absence}

Because the post-decline trawl surveys did not include any eelgrass habitat, and to account for potential temporal variations in fish communities unrelated to eelgrass, fish abundance, size, and species composition were compared in eelgrass habitat and adjacent unvegetated mudflats at two sites in the spring (April-May) of 2017 and 2018 (Fig. 1b). The sites were in the middle portion of the bay (Windy Cove, Fig. 1b) and forebay near the mouth (Coleman's Beach, Fig. 1b). The beach seine used was $10.2 \mathrm{~m}$ long, $1.1 \mathrm{~m}$ high, and had a mesh size of $4 \mathrm{~mm}$.

Seines were conducted at a mean tidal height of $0.43 \pm 0.07$ $\mathrm{m}$ ( \pm standard deviation, $\mathrm{SD})$ relative to mean lower low water (MLLW). At Windy Cove, three replicate seines were conducted in each habitat type in each year. Seines were 20-25 m apart and were a minimum of $10 \mathrm{~m}$ from the edge of the eelgrass and maximum of $175 \mathrm{~m}$ from the edge, with the locations consistent each year. Water depths of the seines varied with bottom rugosity, with a mean water depth of 1.0 $\pm 0.14 \mathrm{~m}$ (SD) in unvegetated mudflats and $1.6 \pm 0.11 \mathrm{~m}(\mathrm{SD})$ in eelgrass. However, given that the height of the seine is $1 \mathrm{~m}$, the depth should not have affected overall catch. Distance of haul depended on depth and eelgrass bed width and ranged from 5.6 to $23.5 \mathrm{~m}$ (mean of $15.9 \pm 1.9 \mathrm{~m} \mathrm{SD}$ ) in the eelgrass, and from 6.4 to $34 \mathrm{~m}$ (mean $19.8 \pm 3.6 \mathrm{~m} \mathrm{SD}$ ) in the mudflats.
At Coleman's Beach, because of adjacent building structures and more continuous eelgrass beds, unvegetated habitat was limited, and only two replicate seines were conducted per year in each habitat type. Furthermore, because of the spacing of unvegetated areas, one of the two eelgrass seines was directly adjacent to the unvegetated habitat, while the other was approximately $10 \mathrm{~m}$ from the edge. Depth in eelgrass habitat was $1.5 \pm 0.04 \mathrm{~m}(\mathrm{SD})$, and in the unvegetated habitat, the depth was $1.6 \pm 0.1 \mathrm{~m}(\mathrm{SD})$. Distance of haul ranged from 8.5 to $12.6 \mathrm{~m}$ (mean $9.4 \pm 0.75 \mathrm{~m} \mathrm{SD}$ ) in the eelgrass and from 5.4 to $8.5 \mathrm{~m}$ in the unvegetated mudflat (mean $5.9 \pm 0.54 \mathrm{~m} \mathrm{SD}$ ). Because of differences in haul distance, fish biomass was standardized by meter of haul for all seines. Fish were identified and measured as described above.

\section{Statistical analyses: trawl surveys (before and after eelgrass decline)}

For each habitat type, models were fitted to assess patterns in total abundance, biomass, species composition, and trophic level. In all models, time period (pre-decline vs. post-decline) was fitted as a predictor, as well as season and an interaction between season and time period since there are seasonal changes in fish abundance, and some fish may be affected by eelgrass loss only during certain times in their lifecycle (e.g., use of nursery habitat). Sampling sites were included as a fixed effect in all models to account for variation among sites. Standard error bars on plots were estimated using a twostage bootstrap approach, in which both sites and samples within sites were randomly sampled with replacement (Field and Welsh 2007).

Generalized linear models with negative binomial and Gamma error distributions were used to assess patterns in abundance and biomass, respectively (R Core Team 2020; Venables and Ripley 2002). A negative binomial distribution was used to account for overdispersed count data and a Gamma distribution to account for deviations from lognormality, based on AIC and the skewness and kurtosis of the 
data (Cullen and Frey 1999; Dick 2004). Changes in average sample trophic level were evaluated using linear regression, weighted by the number of individuals in each trawl. Trophic level estimates and length-to-weight conversion factors (for estimating biomass) were gathered from FishBase, where most species estimates are from published studies, but some are Bayesian estimates based on nearest relatives (Froese and Pauly 2019). Following any significant season by time period interactions, pairwise comparisons (based on the model estimated marginal means) were used to assess differences in abundance and biomass between trawl surveys conducted during the same season pre- and post-decline, as well as between seasons in the same time period (Lenth 2018).

To assess changes in species composition, a permutational multivariate analysis of variance (PERMANOVA) with 10,000 permutations on a Bray-Curtis dissimilarity matrix was fitted for each habitat type using the "vegan" package (Beals 1984; Oksanen et al. 2020). Following significant model interaction terms, pairwise PERMANOVA models were used, with 10,000 permutations per comparison. For any significant pairwise comparisons, similarity percentages (SIMPER) analyses were used to determine which species contributed more than would be expected at random to differences in species composition (Clarke 1993). Differences in species composition were also evaluated graphically using two-dimensional nonmetric multi-dimensional scaling (NMDS) on the Bray-Curtis dissimilarity matrix of species composition. Changes in species richness (number of species per sample) and the Shannon diversity index were evaluated using linear regression.

All data analyses were performed in $\mathrm{R}$ version 4.0.2 ( $\mathrm{R}$ Core Team 2020). Plots were created using the "ggplot2" package (Wickham 2009). All pairwise comparisons in this study were adjusted using the Benjamini and Hochberg method for controlling the rate of false discovery (Benjamini and Hochberg 1995; Pike 2011).

\section{Statistical analyses: beach seines}

Differences between eelgrass and unvegetated habitats were evaluated in terms of fish density, biomass, and species composition. For all models, site, habitat, and the interaction between site and habitat were fitted as predictors. Because seine distance differed between samples, fish abundance was divided by the distance in meters, and is referred to as density. Individual fish lengths and species length-weight relationships were used to estimate biomass density (Froese and Pauly 2019). Fish density and biomass were evaluated using generalized linear models with a Gamma error distribution and a log link. Patterns in species composition were evaluated using a PERMANOVA and SIMPER analyses, as described above.

\section{Results}

\section{Trawl surveys (before and after eelgrass decline)}

\section{Fish abundance and biomass}

In the intertidal flats ( $N=52$ trawls), there was no difference in fish abundance (Table S1a: $p=0.78$ ) or biomass (Table S1b: $p$ $=0.56$ ) corresponding to eelgrass loss (Fig. $2 \mathrm{a}, \mathrm{c}$ ), although fish abundance was higher in the summer (Table S1a: $p=$ 0.04 ) across both the pre- and post-decline periods (Fig. 2a). For fish abundance and biomass in the channel $(N=53$ trawls), there were significant period by season interactions (abundance Table S2a: $p=0.003$; biomass Table S2b: $p<$ 0.001 ; Fig. $2 \mathrm{~d}$ ), with higher fish abundance and biomass in the post-decline period but only in the summer (abundance Table S3a: $p<0.001$, Fig. 2b; biomass Table S3b: $p<$ 0.001 , Fig. 2d).

\section{Species richness, diversity, and trophic level}

The most common species in the intertidal flats in both time periods were bay pipefish (Syngnathus leptorhynchus), arrow goby (Clevelandia ios), staghorn sculpin (Leptocottus armatus), speckled sanddab (Citharichthys stigmaeus), and shiner perch (Cymatogaster aggregata). Eighteen unique species were observed in the intertidal flats before eelgrass decline, and ten after decline. In the channel habitat, the most abundant species (across both time periods) were specked sanddab, staghorn sculpin, English sole (Parophrys vetulus), tube-snout (Aulorhynchus flavidus), and topsmelt (Atherninops affinis). In the channel, 21 unique species were observed before eelgrass decline and 13 were observed after. However, there were no differences in per-trawl diversity indices (either richness or Shannon diversity, Fig. 3) in either the intertidal flats $(N=52$ trawls) or the channel habitats $(N=53$ trawls; Table S4, Table S5). There were also no seasonal differences in diversity indices (Table S4, Table S5, Fig. 3).

Mean sample trophic level was higher in the post-eelgrass decline period in both the intertidal flats (Table S6a: $p<0.001$, $N=51$ ) and the channel (Table S6b: $p<0.001, N=50$ ), but the magnitude of changes was relatively small (Figure S1). In the intertidal flats, there was a significant period by season interaction (Table S6a: $p=0.001$; Figure S1), with a more pronounced increase in the summer in the post-eelgrass decline period (Table $\mathrm{S} 7 ; p<0.001$ ) than in the fall (Table $\mathrm{S} 7 ; p$ $=0.01$ ).

\section{Species composition}

The NMDS plots for both the intertidal flats and the channel show clustering of compositional data by both period and season (Fig. 4). Results of the PERMANOVA confirmed this 
Fig. 2 Total fish abundance $(\mathbf{a}, \mathbf{b})$ and total fish biomass $(\mathbf{c}, \mathbf{d})$ for the intertidal (a, c) and channel (b, d) per trawl during the fall (gray) and summer (black), before and after eelgrass decline. Error bars represent the standard error estimated using a two-stage bootstrap. Significant and nonsignificant differences are shown as solid and dashed lines, respectively
Intertidal Flats
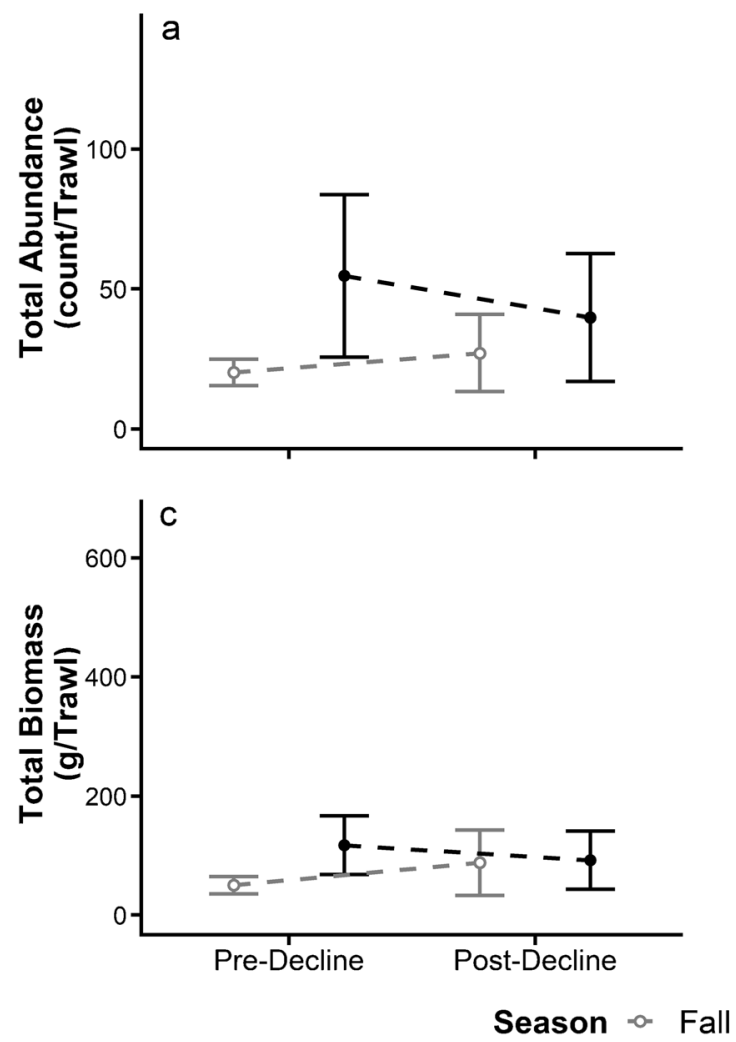

adjusted p-value $-->0.05-<0.05$
Channel
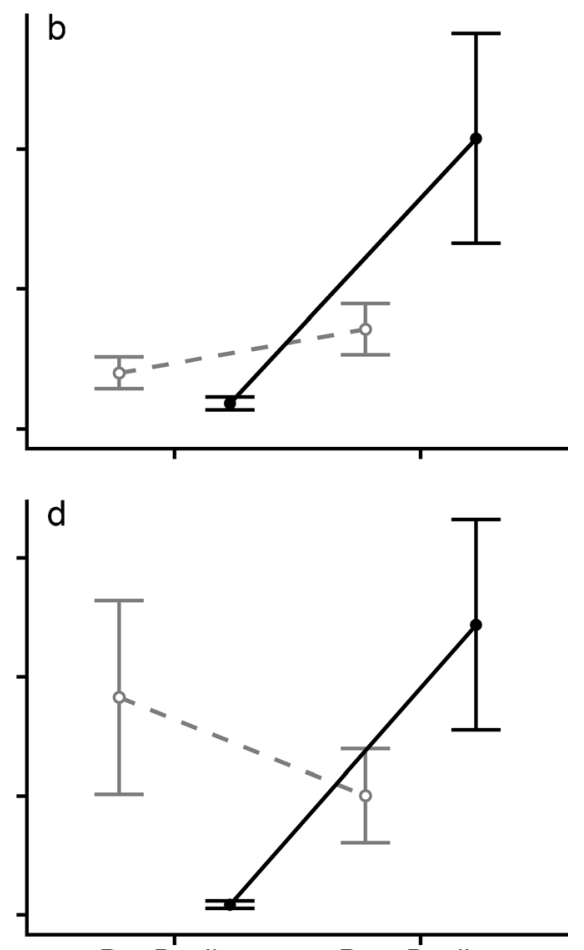

Pre-Decline Post-Decline observation: there were significant differences across period, season, and period by season interaction terms for both the intertidal flats and the channel (Table S8). Species that contributed to observed differences across periods and season are summarized in Table $2 \mathrm{a}-\mathrm{b}$ and described below.

In the intertidal flats, species composition differed across periods (Table S8a: $p<0.001, N=51$ ) in both the fall (Table S9a: $p=0.002, N=51$ ) and the summer (Table S9a: $p=0.01, N=51$ ). The post-decline period was characterized (across both seasons) by fewer bay pipefish (Syngnathus leptorhynchus) and a greater abundance of staghorn sculpin (Leptocottus armatus; Table S10, Fig. 5a, b). There were also seasonal changes: shiner perch (Cymatogaster aggregata) decreased in the post-decline summer, English sole (Parophrys vetulus) increased in the post-decline summer, speckled sanddab (Citharichthys stigmaeus) increased in the postdecline fall, and arrow goby (Clevelandia ios) declined in the post-decline summer but increased in the fall (Table S10, Fig. 5a, b). In the channel, species composition also differed across periods (Table S8b: $p<0.001$, $N=50$ ), but only in the summer (Table S9b: $p=0.001$, $N=50$ ), driven by post-decline increases in speckled sanddab, staghorn sculpin, and English sole (Table S11, Fig. 5c).

\section{Beach seine surveys (inside and outside of remnant eelgrass beds post-decline)}

There was no difference in fish density (Table S12a: $p=0.79$, $N=20$ ) or biomass (Table S12b: $p=0.23, N=20$ ) between eelgrass and unvegetated habitats. There was also no difference across the sites surveyed in overall density (Table S12a: $p=0.36, N=20$ ) or biomass (Table S12b: $p=0.30, N=20$ ). However, there were differences in species composition between habitats and sites (Table S13: $p<0.001, N=20$ in both cases), as well as a significant site by habitat interaction (Table S13: $p=0.006, N=20$, Table S14, Fig. 6). Species that contributed to observed differences across periods and season in each habitat are summarized in Table 2 (part c). In the mid-bay (Windy Cove), eelgrass habitat had a greater abundance of bay pipefish and topsmelt, and a lower abundance of staghorn sculpin than unvegetated habitat (Table S15a, Fig. 6). Near the bay mouth (Coleman's Beach), there was a similarly high abundance of bay pipefish in the eelgrass (with complete absence in the unvegetated habitat; Table S15b, Fig. 6). At the bay mouth, the eelgrass habitat also had higher abundances of kelpfish (Heterostichus rostratus), which were absent in the unvegetated habitat (Table S15b, Fig. 6). However, in contrast to the mid-bay site, near the bay mouth, there were more staghorn sculpin in the 
Fig. 3 Per-sample Shannon diversity $(\mathbf{a}, \mathbf{b})$ and species richness (c, d) for the intertidal flats $(\mathbf{a}, \mathbf{c})$ and the channel $(\mathbf{b}, \mathbf{d})$, before and after eelgrass decline. Error bars represent the standard error estimated using a two-stage bootstrap. There were no changes in Shannon diversity or species richness following eelgrass decline, in either the intertidal flats or the channel, as indicated by the dashed lines
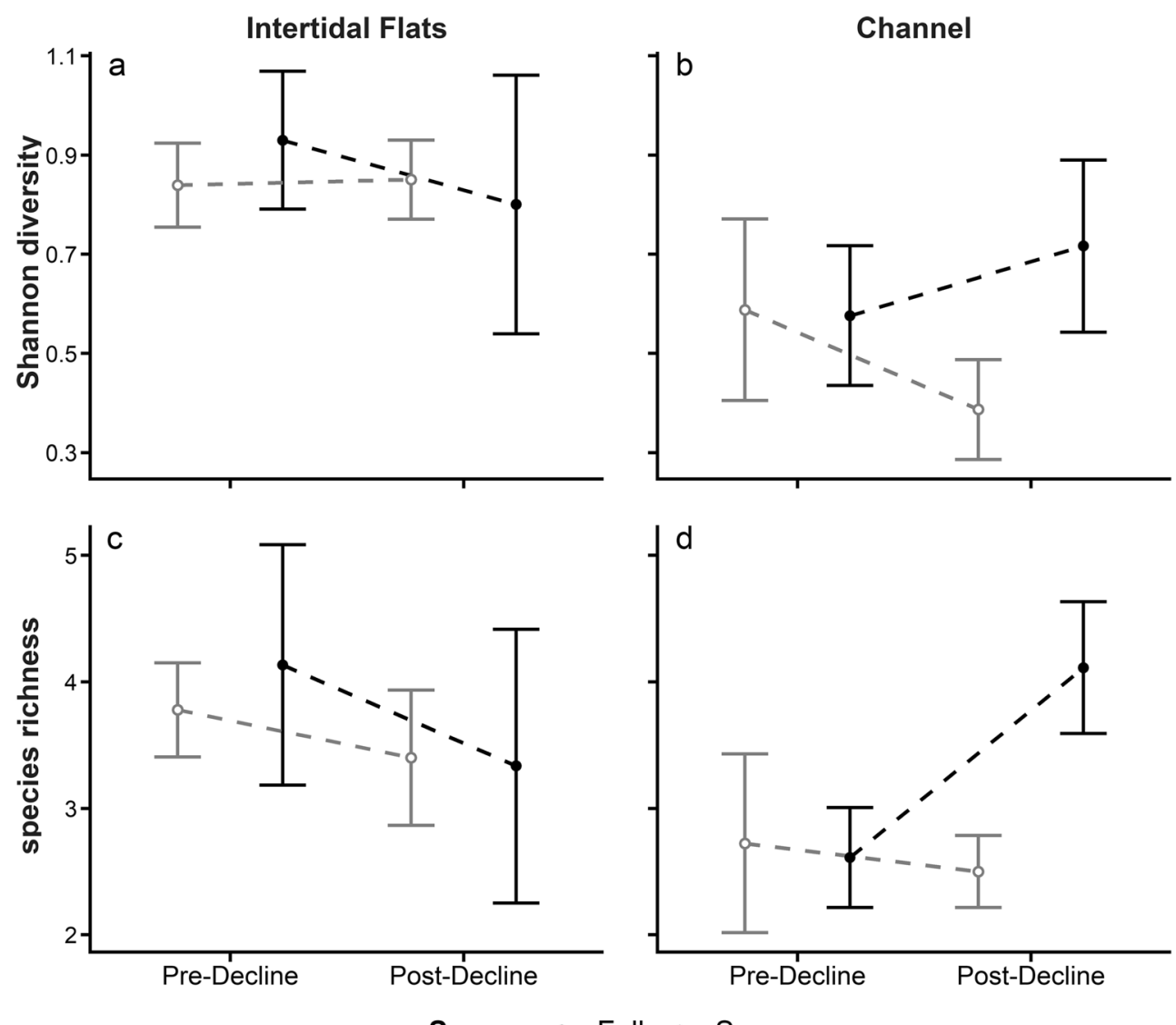

Pre-Decline

Post-Decline eelgrass habitat than in unvegetated habitat (Table S15b, Fig. 6). As in the trawl surveys, at the bay mouth, there were more speckled sanddab in the unvegetated habitat than in eelgrass (Table S15b, Fig. 6).

\section{Discussion}

The ecosystem-wide loss of seagrass in Morro Bay offers a unique opportunity to assess how biogenic habitats structure associated communities. At the sites evaluated, loss of eelgrass did not result in fewer fish or less biomass as hypothesized, but led to changes in species composition. The posteelgrass decline period was generally characterized by increases in flatfish and staghorn sculpin, and decreases in bay pipefish and shiner perch. The comparison of remnant eelgrass patches with unvegetated habitat showed similar trends to the bay-wide assessment: unvegetated habitat had higher abundances of speckled sanddabs and lower abundances of bay pipefish. Compared with historic studies in Morro Bay (1974-1976; Horn 1979), species richness has declined over time, though not across the pre- and post-eelgrass decline periods.

Fish abundance patterns in Morro Bay differed seasonally, which is typical of eastern boundary current marine systems.
These systems tend to have strong seasonal variation in oceanographic conditions (Walter et al. 2018b; Barth et al. 2020), which can lead to complex reproductive behavior and recruitment patterns (e.g., Phelan et al. 2018). While there are relatively few estuary-dependent species, many fish use estuaries as juvenile habitats (Rooper et al. 2006; Hughes et al. 2015). In the intertidal mudflats where eelgrass was formerly abundant, bay pipefish, shiner perch, and staghorn sculpin were more abundant in the summer (June-August), while speckled sanddab were more abundant in the fall (October-November). Bay pipefish are permanent bay residents and prefer eelgrass habitat. Sizes were consistent across seasons, and the observed summer peaks in bay pipefish may represent seasonal increase in food availability (Barry et al. 1996). Shiner perch move to shallow water as distinct schools prior to spawning in early summer and perform elaborate reproductive behavior (Wiebe 1968). Young shiner perch are born a year after the initial spawning between May and August (Wiebe 1968). In the pre-decline period, shiner perch were more abundant in the summer consistent with historic studies in Morro Bay (Fiernstine et al. 1973) and in nearby Elkhorn Slough (Barry and Cailliet 1981). However, their summer abundance declined in intertidal mudflats following eelgrass loss. Staghorn sculpin often dominate estuarine fish communities by both abundance and biomass (Bottom and Jones 1990; 
Fig. 4 Two-dimensional ordination (NMDS) of species composition data from trawl surveys for intertidal flats (a, stress $=0.19)$ and channel $(\mathbf{b}$, stress $=0.16$ ). Sampling period is indicated by color (blue, predecline; red, post-decline) and shape (circle, fall; triangle, summer)

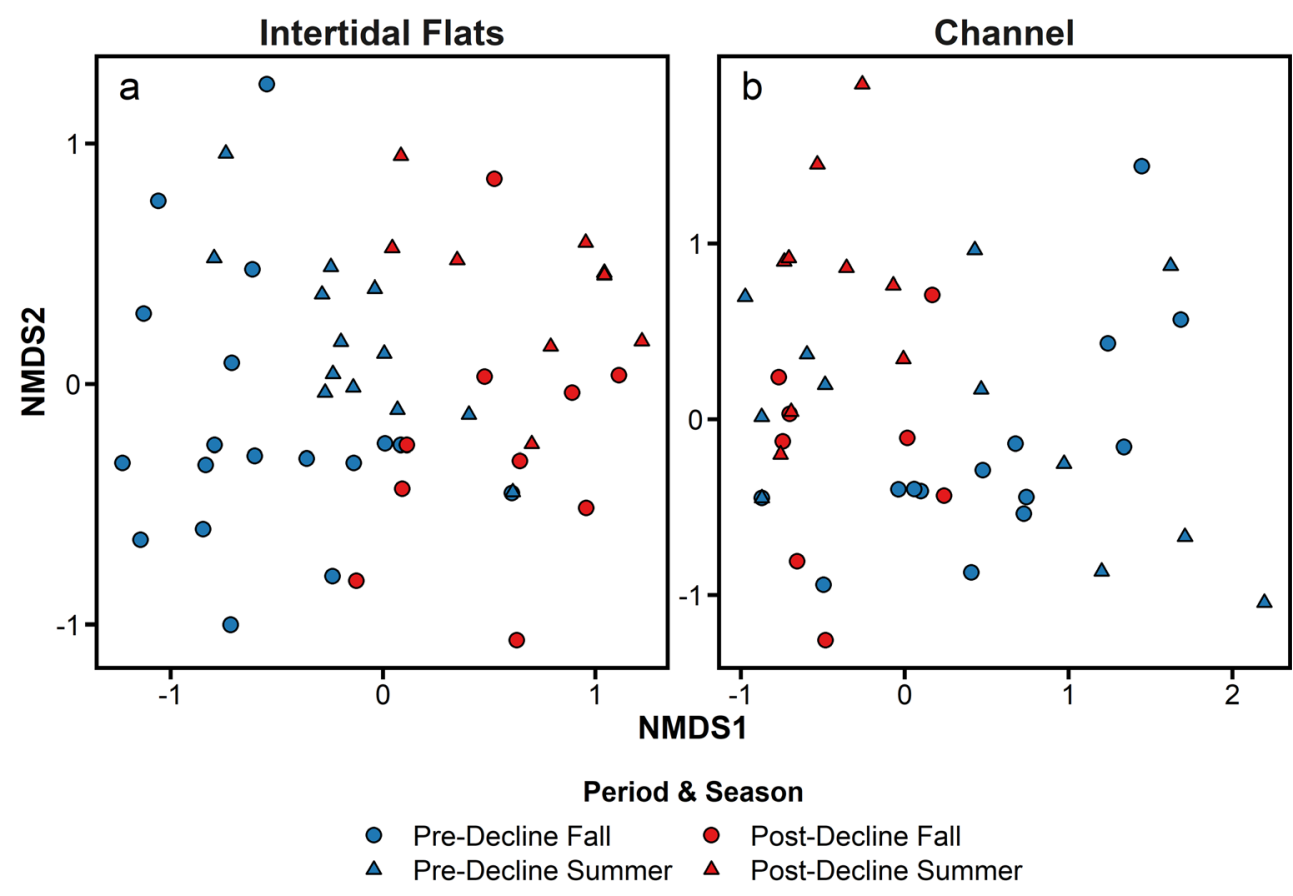

Table 2 Summary of species composition differences between seasons within a period and between periods within a season for a intertidal flats (former eelgrass) habitat, $\mathbf{b}$ channel habitat, and $\mathbf{c}$ beach seine surveys in adjacent eelgrass and unvegetated habitat. Species listed are those that contributed to compositional differences between seasons with a period, or between periods within a season, according to a SIMPER analysis. A "n.s." denotes a comparison (between seasons or periods) that was nonsignificant based on pairwise PERMANOVA comparisons. Blank cells indicate that for the given comparison, the particular species did not contribute to observed differences in species composition (based on SIMPER analysis) a) Intertidal flats (former eelgrass habitat)

Species

Arrow goby

Bay pipefish

English sole

Shiner perch

Speckled sanddab

Staghorn sculpin

b) Channel

Species

Bay pipefish

English sole

Speckled sanddab

Staghorn sculpin

Tubesnout

c) Beach seine surveys (unvegetated habitat relative to eelgrass habitat)

Species

Bay pipefish

Giant kelpfish

Speckled sanddab

Staghorn sculpin

Topsmelt
Period comparison

(post relative to pre)

In summer

$-$

$-$

$+$

$-$

Period comparison (relative to pre)

In summer

$+$

$+$

$+$

In fall
+
-

+
+

$+$

In fall
n.s.
n.s.
n.s.
n.s.
n.s.

Seasonal comparison

\begin{tabular}{|c|c|}
\hline In pre & In post \\
\hline + Summer & + Fall \\
\hline + Summer & + Summer \\
\hline + Summer & \\
\hline & + Fall \\
\hline
\end{tabular}

Seasonal comparison

$\begin{array}{ll}\text { In pre } & \text { In post } \\ + \text { Fall } & \\ & + \text { Summer } \\ + \text { Fall } & + \text { Summer } \\ & + \text { Summer }\end{array}$


Fig. 5 Species abundances (natural $\log (+1)$ before (light gray) and after (dark gray) eelgrass decline for a intertidal flats in the fall, $\mathbf{b}$ intertidal flats in the summer, and $\mathbf{c}$ the channel in the summer. Species composition did not differ between pre-decline and post-decline periods for the channel in the fall based on a pairwise PERMANOVA. Species shown are those identified by a SIMPER analysis as contributing most to observed differences in species composition; standard errors are estimated using a twostage bootstrap. Where there were no individuals of a species for a particular period and habitat, this is indicated with a zero
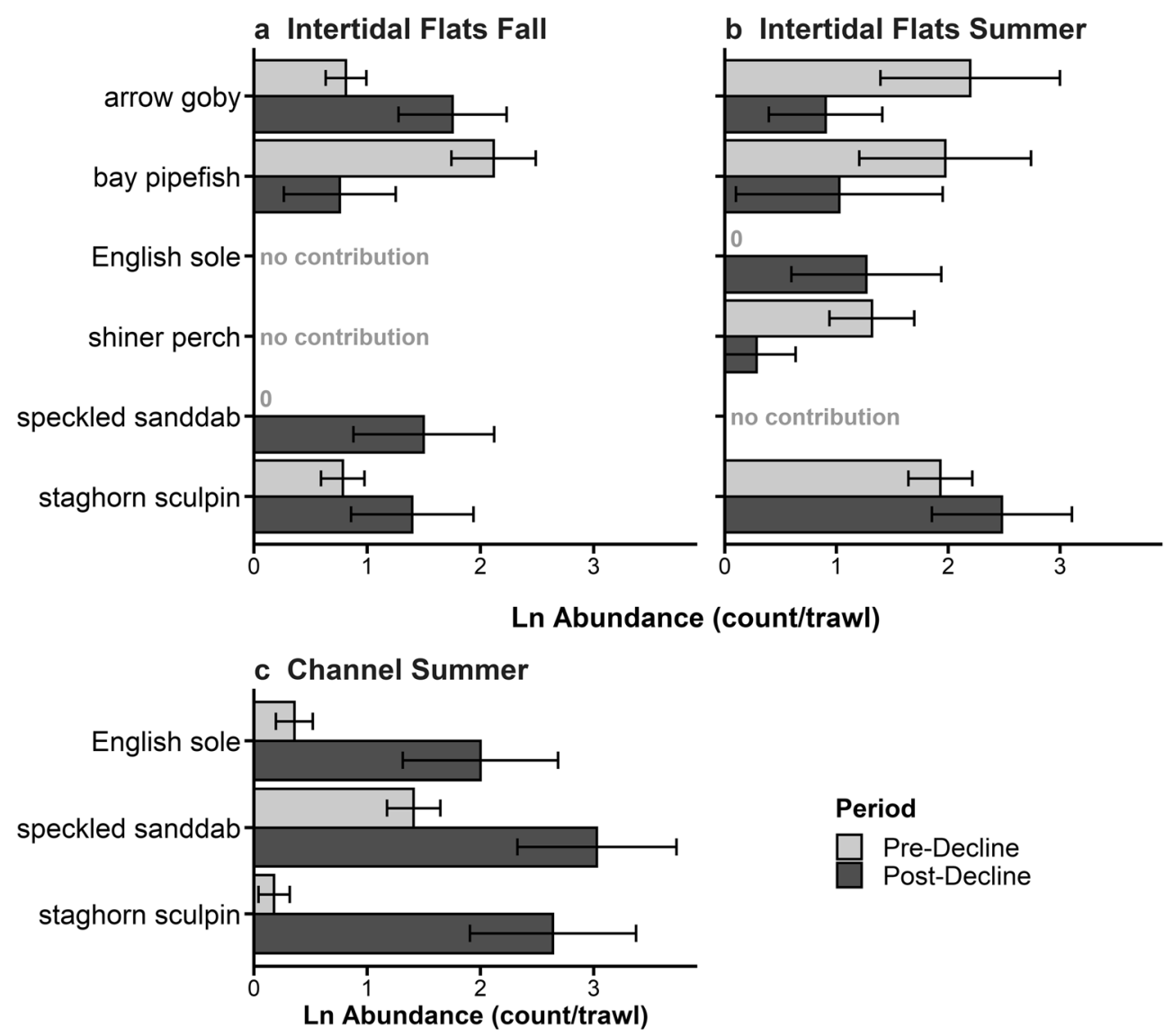

Monaco et al. 2009). This species commonly uses estuarine habitat for spawning between October and March, with eggs hatching approximately 2 weeks later, and juveniles remaining in estuarine habitat until they move to deeper waters as adults (Moyle and Cech 2004; Miller 2007). In this study, staghorn sculpin were abundant in the summer months in both the pre-and post-decline period. Based on their mean length (78 mm), most were juveniles below sexual maturity (Horn 1979). Though staghorn sculpin increased in relative abundance in the post-eelgrass decline period, beach seine data indicate that they have a site-dependent reliance on eelgrass (e.g., near the bay mouth) which could be related to predation
Fig. 6 Density of species contributing to observed differences in community structure between unvegetated habitats (dark gray) and eelgrass (light gray) based on a SIMPER analysis from beach seine data for: Coleman Park Beach (mouth), and Windy Cove (midbay). Where there were no individuals of a species at a site, this is indicated with a zero

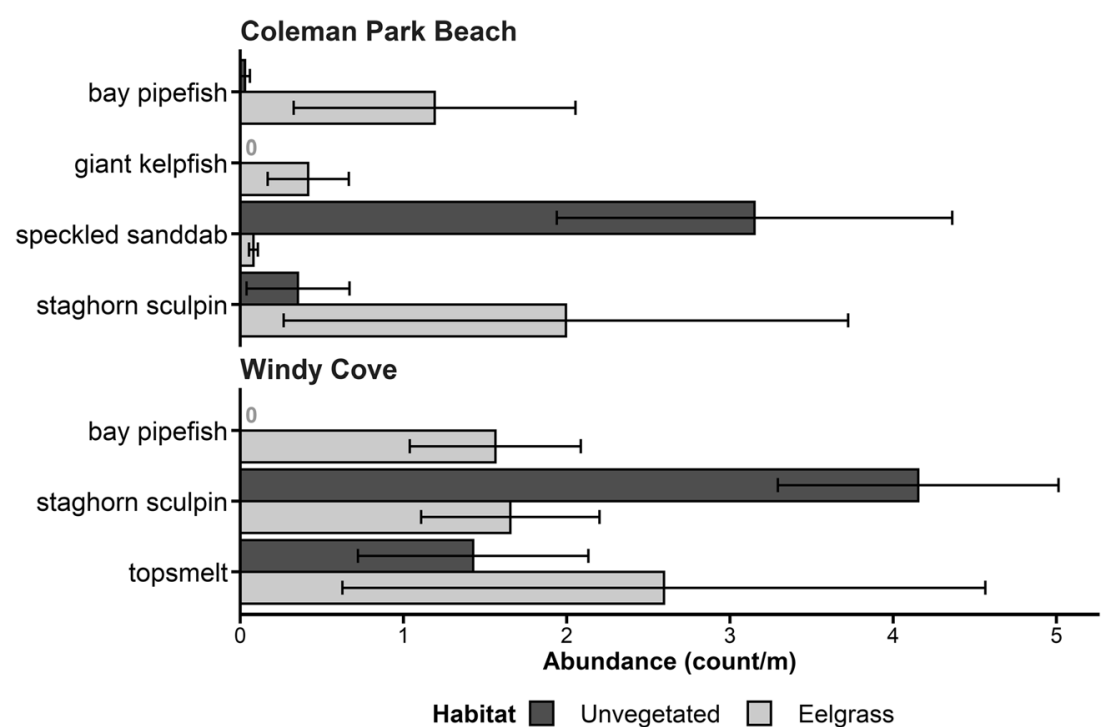


pressure, though this requires additional studies. Speckled sanddab were in the juvenile range (20-90 $\mathrm{mm}$; Love 2020), consistent with their use of estuaries as nursery habitat during this stage.

In addition to seasonal fluctuations, fish recruitment is influenced by a host of oceanographic processes and environmental factors that vary interannually. Between 2014 and 2016, ocean temperatures were abnormally high along the California coast due to the North Pacific marine heatwave (Di Lorenzo and Mantua 2016; Gentemann et al. 2017). This warming event, which lasted until the spring of 2016, could have affected recruitment, movement, and survival patterns prior to the fall 2016 and summer 2017 surveys, and it is possible that some seasonal or periodic changes in species composition are associated with this event. This study is limited to data from before and after the decline, and further postdecline trawl surveys have been prohibited by regulatory agencies. However, by conducting beach seine surveys in the post-decline period in adjacent eelgrass and unvegetated habitats, the influence of eelgrass habitat and its absence was evaluated during the same time period. As in the trawl surveys, beach seine surveys showed differences in species composition, but no difference in fish count or biomass between eelgrass and adjacent unvegetated habitat. Within the remnant eelgrass habitat, two additional species were also identified, topsmelt and juvenile giant kelpfish. Topsmelt are important forage fish for larger fishes, California sea lions, harbor seals, numerous sea birds, and Brandt geese (Brodeur and Buchanan 2014). Since topsmelt females deposit eggs directly on eelgrass (Williams and Zedler 1999), their populations are likely reduced with the bay-wide loss of eelgrass habitat, and beach seine surveys showed fewer topsmelt in unvegetated habitats. While there were no differences in topsmelt abundance in the pre- and post-decline trawl surveys, it is likely that these fish were under-sampled by the benthic trawls as they tend to reside above the bottom in mid or surface waters. A key difference between trawl and seine surveys was in the response of shiner perch to eelgrass absence. In contrast to the trawl surveys (where shiner perch declined in the post-eelgrass decline period), shiner perch did not decline in unvegetated habitats in the beach seine surveys. Shiner perch were abundant in the beach seine surveys, and the lack of difference in adjacent eelgrass and unvegetated habitats may indicate that they use eelgrass habitat but can move outside on small scales $(\sim 500 \mathrm{~m}$ spacing between seines), though this requires additional studies. Shiner perch have an affinity for structural habitat, and previous studies have shown higher abundances of shiner perch in eelgrass than in kelp or algal than in unvegetated habitats (Murphy et al. 2000).

Typically, investigations of the importance of biogenic habitat on inhabitants involve comparisons between adjacent areas with and without a habitat or small-scale habitat removal experiments (Underwood 1995; Airoldi et al. 2008), which limit the ability to make inferences to entire ecosystems. In most other systems that have experienced seagrass declines, declines either led to partial seagrass loss or fish population data were not available before the decline. Fish populations often only respond to seagrass loss when loss reaches a certain threshold (Yeager et al. 2016), so studies of partial loss may not predict ecosystem-level response. For example, a study in North Carolina (USA) found that fish community structure and richness did not respond until seagrass reached $<25 \%$ cover, driven by the absence of epibenthic species at low seagrass cover (Yeager et al. 2016). There were two examples identified in a literature review of system-wide seagrass collapse in which fishes had been assessed before and after decline. A small (7 ha) seagrass bed that was lost in Japan following a 2009 typhoon resulted in losses in fish species richness (75\% reduction) and abundance (85\% reduction) compared to a control site (Nakamura 2010). In Portugal, the Mira Estuary experienced large-scale seagrass losses and had associated losses of fish species richness, diversity, and abundance, with some species disappearing (Castro et al. 2019). There was one example identified of a temporary seagrass collapse in the Kariega Estuary in South Africa due to flooding in 2012, with full recovery over the subsequent 4 years (Wasserman et al. 2020). In this case, abundance of an estuary-dependent marine sparid (family Sparidae) tracked trends in eelgrass coverage, especially in juvenile age classes (Wasserman et al. 2020). In other cases, the lack of pre-habitat decline fish data has been a challenge. For example, in Cockburn Sound in Western Australia, a bay lost $>3000$ ha of seagrass between 1950 and 1970 , but there were no predecline data; however, post-decline comparisons of beaches with and without seagrass showed shifts in species composition (Vanderklift and Jacoby 2003).

A literature review revealed additional studies of partial seagrass loss with variable fish community responses across five systems: Massachusetts, Chesapeake Bay, and Florida along the US East Coast; the Skegerrak archipelago in Sweden; and in comparisons of vegetated and unvegetated estuaries in southern Australia. Seagrass loss resulted in declines in fish abundance and biomass in two cases: a localized eelgrass decline in Massachusetts (Hughes et al. 2002) and a $60 \%$ eelgrass decline in the Swedish Skegerrak archipelago (Pihl et al. 2006). In three cases, species richness or diversity was reduced: Massachusetts (Hughes et al. 2002), the Skegerrak archipelago (Pihl et al. 2006), as well as in a 29\% eelgrass decline in the Chesapeake Bay (Lefcheck et al. 2017; Sobocinski et al. 2013). However, in Florida Bay, a loss of more than 4000 ha of seagrass (Robblee et al. 1991) resulted in an increase in species richness attributed to the habitat mosaic created by patchy seagrass die-off (Matheson et al. 1999). In four of the five studies, seagrass loss led to altered community composition: in the Chesapeake Bay (Sobocinski et al. 2013); in Florida Bay with declines in seagrass associated 
species and increases in benthic species (Matheson et al. 1999); in the Skegerrak archipelago with losses or near absence of some groups of fishes in unvegetated areas (gadoids, labrids, syngnathids; Pihl et al. 2006); and in southern Australia where eelgrass estuarine sites were dominated with the syngnathid Stigmatopora nigra and juvenile whiting Sillaginodes punctata (a species of economic importance), while unvegetated estuarine sites were dominated by the flounder Rhombosolea tapirina (Connolly 1994). Thus, loss of seagrass (whether partial or ecosystem-wide) appears to consistently lead to shifts in species composition, with losses of specialist species (e.g., syngnathids) and increases in benthic species (e.g., flatfish), and often to reductions in species richness or diversity, except when seagrass loss increases habitat patchiness. However, declines in species abundance or biomass do not seem ubiquitous.

Whether or not loss of biogenic habitat leads to an overall decline in fish abundance or biomass may be dictated by the predominance of habitat-specialists and the ability of other species to expand into unstructured habitat space. This has been widely assumed, but rarely tested in marine systems (Pratchett et al. 2012). This is the case in coral reef systems where widespread bleaching has led to losses of coral habitat over large spatial scales. An examination of the effects of the 1998 mass bleaching event spanning seven countries and 66 sites in the Indian Ocean found that the loss of corals did not lead to overall loss of fish abundance, but led to loss of species richness and changes in species composition with the loss of specialist species (e.g., obligate corallivores, planktivorous damselfish, and small fishes at risk of predation), but no change in generalist fishes (e.g., herbivore or mixed diet species; Graham et al. 2008). Similarly, on the Great Barrier Reef, mass bleaching in 2016 led to loss of obligate corallivores across 186 sites (Stuart-Smith et al. 2018). Smallerscale reef studies show similar findings, indicating that the proportional decline in the abundance of each species relates to the degree of habitat specializations (Munday 2004). The findings of the present study also indicate that habitat declines disproportionally impact specialists.

Resource specialization in marine fishes can therefore increase extinction risk as biogenic habitats decrease. In addition to reducing the abundance of habitat specialists, loss of habitat across seascapes is likely to restrict population connectivity and can lead to range contraction (Goodman et al. 2019). Specialist species are also more prone to extinction due to climate change because of lower colonization and dispersal ability (Mantyka-Pringle et al. 2012). Along the Pacific Coast of the United States, estuaries are widely spaced, and eelgrass is therefore a relatively uncommon habitat. For estuarine fish, each estuary may act as a crucial link to other estuaries allowing coast-wide connectivity. The bay pipefish (S. leptorhynchus) is part of the genus Syngnathus, which is typically strongly associated with eelgrass habitat (e.g., Whitfield et al. 2017). Bay pipefish range from Alaska to Baja California, and Morro Bay (California) serves as a boundary between two possible sub-species with different meristic characteristics (Herald 1941; Wilson 2006). A complete loss of eelgrass in Morro Bay will increase the distance between nearby eelgrass beds, resulting in approximately 400-500 km distance between Elkhorn Slough to the north and eelgrass beds on the Channel Islands or Santa Monica Bay to the south. Thus, the loss of eelgrass in Morro Bay may serve to genetically isolate bay pipefish sub-populations, making them more vulnerable. In North America, close to a third of the marine fishes and invertebrates surveyed off the coasts have already exhibited range contractions or regional declines in abundance (McCauley et al. 2015). There is also growing evidence suggesting that climate change will interact synergistically with habitat loss and disproportionally contribute to the loss of species diversity (Mantyka-Pringle et al. 2012).

Changes in species abundance and loss of diversity can also affect trophic levels and food webs. The results in the present study suggest that loss of eelgrass in Morro Bay was associated with a shift to species of a higher trophic level at the sites evaluated. By trophic category, the change is minor as most fish were secondary consumers before and after the decline. Fishes that increased, staghorn sculpin and speckled sanddabs, consume epifaunal crustacea, with lesser ingestion of infaunal and epifaunal worms (Barry et al. 1996). Shiner perch, which declined in bay-wide trawl surveys, has a similar diet (Barry et al. 1996). Bay pipefish, which declined, generally feed on planktonic crustaceans (Froese and Pauly 2019). Thus, similar to the nearest estuary (Elkhorn Slough; Barry et al. 1996), Morro Bay appears to have few fish species that rely directly on primary production (consumption of algae or phytoplankton), with fish predating mainly on detritusconsuming prey such as copepods, amphipods, and polychaete worms. Small crustacea and polychaete worms respond rapidly to increases in micro- and macro-algal blooms during spring and summer, increasing food availability to fishes (Barry et al. 1996), and this may explain some of the seasonal patterns observed. Some of the fish species that declined play an important role in controlling eelgrass faunal communities. Both bay pipefish and shiner perch are key predators of a nonnative amphipod (Ampithoe valida) found in San Francisco Bay (USA, along the same coastline approximately $300 \mathrm{~km}$ to the north) that consumes large quantities of eelgrass (Carr and Boyer 2014). Conversely, pipefish predation of grazing amphipods (mesograzers) in eelgrass beds can increase epiphytic algal overgrowth and be detrimental to eelgrass in systems with high primary productivity and nutrient ability (Jorgensen et al. 2007). Understanding whether estuarinewide declines in bay pipefish are affecting eelgrass herbivory 
or epiphytic growth in remnant beds in Morro Bay requires additional studies.

Finally, in the portions of the estuary where eelgrass loss was most dramatic (back bay), previous work documented higher turbidities and temperatures, as well as lower dissolved oxygen conditions (and more frequent hypoxic conditions), compared to the bay mouth (Walter et al. 2018a). In Elkhorn Slough ( $200 \mathrm{~km}$ away), hypoxic conditions had strong negative effects on the abundance of flatfish (English sole and speckled sanddab; Hughes et al. 2015). Thus, if water conditions in Morro Bay continue to deteriorate, this could have adverse effects on the flatfish populations now dominating the bay, causing further system decline.

\section{Conclusions}

The estuary-wide loss of eelgrass in Morro Bay did not lead to fish abundance or biomass declines, but rather led to changes in species composition with increases in flatfish and sculpins and declines in habitat specialists like the bay pipefish. These results support evidence that the response of fish abundance to habitat loss depends on the relative abundance of habitat specialists, which could be used as a predictor of ecosystem response to habitat loss. However, future research is needed to determine other ecosystem or community attributes that promote maintenance of fish biomass amid habitat change. In addition, given that species composition shifts appear to be relatively common following major habitat loss, it is important to evaluate how such structural changes in fish communities affect ecosystem function including trophic dynamics for other taxa. In Morro Bay, if eelgrass loss was to continue, it would increase the scale of eelgrass habitat discontinuity along the US West Coast. For specialist species (e.g., bay pipefish), this could disrupt connectivity and shift the genetic structure of populations.

Global studies on ecosystem resilience suggest that the presence of remnant habitat patches is important for recovery of ecosystem structure and function (Lotze et al. 2011; O'Leary et al. 2017). Despite the scale of eelgrass decline, Morro Bay has remnant beds that may allow future recovery, and protection of these beds is critical. Generally, the most common tool for habitat protection is developing networks of marine protected areas (MPAs) through marine spatial planning. However, MPAs alone may not be enough to protect critical habitats: in Morro Bay, the entire bay is protected in two MPAs, a state marine reserve and a state recreational management area. It has been challenging to determine the cause of eelgrass decline in Morro Bay given the paucity of pre-decline data, but it may be due to sediment dynamics (Walter et al. 2018a; Walter et al. 2020). Thus, where maintaining fish populations depends on protecting critical habitat, management will require multi-faceted approaches that couple marine spatial planning with other local ecosystem-based management measures such as upstream management.

Supplementary Information The online version contains supplementary material available at https://doi.org/10.1007/s12237-021-00917-2.

Acknowledgements We are grateful for the field support provided by $\mathrm{T}$. Moylan and R. Brewster from California Polytechnic State University for boat and trawl operation during field sampling.

Funding The California State University (CSU); CSU Council on Ocean Affairs, Science \& Technology (COAST); and California Sea Grant provided funding for this study.

\section{References}

Airoldi, L., D. Balata, and M.W. Beck. 2008. The gray zone: relationships between habitat loss and marine diversity and their applications in conservation. Journal of Experimental Marine Biology and Ecology 366 (1-2): 8-15.

Barry, J.P., and G.M. Cailliet. 1981. The utilization of shallow marsh habitats by commercially important fishes in Elkhorn Slough, California. Cal-Neva Wildlife Transactions 1981: 38-34.

Barry, J.P., M.M. Yoklavich, G.M. Cailliet, D.A. Ambrose, and B.S. Antrim. 1996. Trophic ecology of the dominant fishes in Elkhorn Slough, California, 1974-1980. Estuaries 19 (1): 115-138.

Barth, A., R.K. Walter, I. Robbins, and A. Pasulka. 2020. Seasonal and interannual variability of phytoplankton abundance and community composition on the Central Coast of California. Marine Ecology Progress Series 637: 29-43.

Beals, E.W. 1984. Bray-Curtis Ordination: an effective strategy for analysis of multivariate ecological data. Advances in Ecological Research 14: 1-55.

Beck, M.W., K.L. Heck, K.W. Able, D.L. Childers, D.B. Eggleston, B.M. Gillanders, B.S. Halpern, C.G. Hays, K. Hoshino, T.J. Minello, R.J. Orth, P.F. Sheridan, and M.P. Weindstein. 2001. The identification, conservation, and management of estuarine and marine nurseries for fish and invertebrates. BioScience 51 (8): 633-641.

Benjamini, Y., and Y. Hochberg. 1995. Controlling the false discovery rate: a practical and powerful approach to multiple testing. Journal of the Royal Statistical Society: Series B: Methodological 57 (1): 289-300.

Bottom, D.L., and K.K. Jones. 1990. Species composition, distribution and invertebrate prey of fish assemblages in the Colombia River estuary. Progress in Oceanography 25 (1-4): 243-270.

Brodeur, R.D., and J.L.E. Buchanan. 2014. Pelagic and demersal fish predators on juvenile and adult forage fishes in the northern California current: spatial and temporal variations. CalCOFI Report 55: 96-116.

Carr, L.A., and K.E. Boyer. 2014. Variation at multiple trophic levels mediates a novel seagrass-grazer interaction. Marine Ecology Progress Series 508: 117-128.

Castro, N., C. Penedos, P. Félix, P. Chainho, T. Pereira, M. Costa, A.J. Almeida, H. Adão, and J.L. Costa. 2019. Structural and functional composition of fish communities associated to Zostera noltii 
meadows as a response to natural habitat recovery. Ecological Indicators 106: 105435.

Clarke, K.R. 1993. Non-parametric multivariate analyses of changes in community structure. Australian Journal of Ecology 18 (1): 117143.

Connolly, R.M. 1994. A comparison of fish assemblages from seagrass and unvegetated areas of a southern Australian estuary. Marine and Freshwater Research 45 (6): 1033-1044.

Cullen, A.C., and C.H. Frey. 1999. Probabilistic techniques in exposure assessment. New York: Plenum Press.

Di Lorenzo, E., and N. Mantua. 2016. Multi-year persistence of the 2014/15 North Pacific marine heatwave. Nature Climate Change 6 (11): 1042-1047.

Dick, E.J. 2004. Beyond 'lognormal versus gamma': discrimination among error distributions for generalized linear models. Fisheries Research 70 (2-3): 351-366.

Duarte, C.M. 2002. The future of seagrass meadows. Environmental Conservation 29 (2): 192-206.

Dulvy, N.K., Y. Sadovy, and J.D. Reynolds. 2003. Extinction vulnerability in marine populations. Fish and Fisheries 4 (1): 25-64.

Elliott, M., N.D. Cutts, and A. Trono. 2014. A typology of marine and estuarine hazards and risks as vectors of change: a review for vulnerable coasts and their management. Ocean and Coastal Management 93: 88-99.

Field, C.A., and A.H. Welsh. 2007. Bootstrapping clustered data. Journal of the Royal Statistical Society: Series B: Methodological 69 (3): 369-390.

Fiernstine, H.L., K.F. Kline, and G.R. Garman. 1973. Fishes collected in Morro Bay, California between January 1968 and December 1970. California Deparment of Fish and Game 59 (1): 73-88.

Fischer, J., and D.B. Lindenmayer. 2007. Landscape modification and habitat fragmentation: a synthesis. Global Ecology and Biogeography 15: 55-66.

Froese, R., and D. Pauly. 2019. FishBase. World Wide Web electronic publication. www.fishbase.org, version (12/2019). Accessed 1 September 2010.

Gentemann, C.L., M.R. Fewings, and M. García-Reyes. 2017. Satellite sea surface temperatures along the West Coast of the United States during the 2014-2016 northeast Pacific marine heat wave. Geophysical Research Letters 44 (1): 312-319.

Goodman, M.C., S.M. Hannah, and B.I. Ruttenberg. 2019. The relationship between geographic range extent, sea surface temperature and adult traits in coastal temperate fishes. Journal of Biogeography 46: $1438-1450$

Graham, N.A.J., T.R. McClanahan, M.A. MacNeil, S.K. Wilson, N.V.C. Polunin, S. Jennings, P. Chabanet, S. Clark, M.D. Spalding, Y. Letourneur, L. Bigot, R. Galzin, M.C. Ohman, K.C. Garpe, A.J. Edwards, and C.R. Sheppard. 2008. Climate warming, marine protected areas and the ocean-scale integrity of coral reef ecosystems. PLoS One 3 (8): e3039.

Hansen, J., G. Sundblad, U. Bergström, Å. Austin, S. Donadi, B.K. Eriksson, and J. Eklöf. 2019. Recreational boating degrades vegetation important for fish recruitment. Ambio 48: 539-551.

Heck, K.L., G. Hays, and R.J. Orth. 2003. Critical evaluation of the nursery role hypothesis for seagrass meadows. Marine Ecology Progress Series 253: 123-136.

Hemminga, M.A., and C.M. Duarte. 2000. Seagrass Ecology. Cambridge: Cambridge University Press.

Herald, E.S. 1941. A systematic analysis of variation in the western American pipefish, Syngnathus californiensis. Stanford Ichthyol. Bull 2(3): 49-73.

Hoekstra, J.M., T.M. Boucher, T.H. Ricketts, and C. Roberts. 2005. Confronting a biome crisis: global disparities of habitat loss and protection. Ecology Letters 8: 23-29.
Horn, M.H. 1979. Diel and seasonal variation in abundance and diversity of shallow water fish populations in morro Bay, California. Fishery Bulletin 78: 759-770.

Hughes, J.E., L.A. Deegan, J.C. Wyda, M.J. Weaver, and A. Wright. 2002. The effects of eelgrass habitat loss on estuarine fish communities of southern New England. Estuaries 25 (2): 235-249.

Hughes, B.B., M.D. Levey, M.C. Fountain, A.B. Carlisle, F.P. Chavez, and M.G. Gleason. 2015. Climate mediates hypoxic stress on fish diversity and nursery function at the land-sea interface. Proceedings of the National Academy of Sciences of the United States of America 112 (26): 8025-8030.

Jackson, J.B.C. 2008. Colloquium paper: ecological extinction and evolution in the brave new ocean. Proceedings of the National Academy of Sciences of the United States of America 105 (Supplement 1): $11458-11465$.

Jorgensen, P., S.E. Ibarra-Obando, and J.D. Carriquiry. 2007. Top-down and bottom-up stabilizing mechanisms in eelgrass meadows differentially affected by coastal upwelling. Marine Ecology Progress Series 333: 81-93.

Krause-Jensen, D., C.M. Duarte, K. Sand-Jensen, and J. Carstensen. 2020. Century-long records reveal shifting challenges to seagrass recovery. Global Change Biology 27 (3): 563-575.

Lefcheck, J.S., D.J. Wilcox, R.R. Murphy, S.R. Marion, and R.J. Orth. 2017. Multiple stressors threaten the imperiled coastal foundation species eelgrass (Zostera marina) in Chesapeake Bay, USA. Global Change Biology 23 (9): 3474-3483.

Lefcheck, J.S., B.B. Hughes, A.J. Johnson, B.W. Pfirrmann, D.B. Rasher, A.R. Smyth, B.L. Williams, M.W. Beck, and R.J. Orth. 2019. Are coastal habitats important nurseries? A meta-analysis. Conservation Letters 12: e12645.

Lenth, R. (2018). emmeans: estimated marginal means, aka least-squares means. Retrieved from https://cran.r-project.org/package= emmeans. Accessed 1 Sept 2020.

Ling, S.D., R.E. Scheibling, A. Rassweiler, C.R. Johnson, N. Shears, S.D. Connell, A.K. Salomon, K.M. Norderhaug, A. Perez-Matus, J.C. Hernandez, S. Clemente, L.K. Blamey, B. Hereu, E. Ballesteros, E. Sala, J. Garrabou, E. Cebrian, M. Zabala, D. Fujita, and L.E. Johnson. 2015. Global regime shift dynamics of catastrophic sea urchin grazing. Philosophical Transactions B 370 (1659): 20130269.

Lotze, H.K., H.S. Lenihan, B.J. Bourque, R.H. Bradbury, R.G. Cooke, M.C. Kay, S.M. Kidwell, M.X. Kirby, C.H. Peterson, and J.B.C. Jackson. 2006. and Coastal Seas. Science 312: 1806-1809.

Lotze, H.K., M. Coll, A.M. Magera, C. Ward-Paige, and L. Airoldi. 2011. Recovery of marine animal populations and ecosystems. Trends in Ecology \& Evolution 26 (11): 595-605.

Love, M.S. 2020. Certainly more than you want to knom about the fishes of the Pacific coast. Santa Barbara: Really Big Press.

Lu, Y., J. Yuan, X. Lu, C. Su, Y. Zhang, C. Wang, X. Cao, Q. Li, J. Su, V. Ittekkot, R.A. Garbutt, S. Bush, S. Fletcher, T. Wagey, A. Kachur, and N. Sweijd. 2018. Major threats of pollution and climate change to global coastal ecosystems and enhanced management for sustainability. Environmental Pollution 239: 670-680.

Mantyka-Pringle, C.S., T.G. Martin, and J.R. Rhodes. 2012. Interactions between climate and habitat loss effects on biodiversity: a systematic review and meta-analysis. Global Change Biology 18 (4): 12391252.

Matheson, R.E., D.K. Camp, S.M. Sogard, and K.A. Bjorgo. 1999. Changes in seagrass-associated fish and crustacean communities on Florida Bay mud banks: the effects of recent ecosystem changes? Estuaries 22 (2): 534-551.

Maxwell, P., J. Eklof, M. van Katwijk, K. O’Brien, M. de la Torre-Castro, M. Bostrom, C. Bouma, T. Krause-Jensen, D. Unsworth, B.I. van Tussenbroek, and T. van der Heide. 2017. The fundamental role of ecological feedback mechanisms for the adaptive management of 
seagrass ecosystems - a review. Biological Reviews 92 (3): 15211538.

McCauley, D.J., M.L. Pinsky, S.R. Palumbi, J.A. Estes, F.H. Joyce, and R.R. Warner. 2015. Marine defaunation: animal loss in the global ocean. Science 347 (6219): 1255641.

McClenachan, L., G. O'Connor, B.P. Neal, J.M. Pandolfi, and J.B.C. Jackson. 2017. Ghost reefs: nautical charts document large spatial scale of coral reef loss over 240 years. Science Advances 3: 1-8.

McCloskey, R.M., and R.K.F. Unsworth. 2015. Decreasing seagrass density negatively influences associated fauna. PeerJ 3: e1053.

Miller, J.A. 2007. Scales of variation in otolith elemental chemistry of juvenile staghorn sculpin (Leptocottus armatus) in three Pacific Northwest estuaries. Marine Biology 151 (2): 483-494.

Monaco, M.E., T.A. Lowery, and R.L. Emmett. 2009. Assemblages of U.S. West coast estuaries based on the distribution of fishes. Journal of Biogeography 19 (3): 251-267.

Moyle, P.B., and J.J. Cech. 2004. Fishes: an introduction to ichthyology. 5th ed. Upper Saddle River: Pearson Prentice Hall.

Mumby, P.J., A. Hastings, and H.J. Edwards. 2007. Thresholds and the resilience of Caribbean coral reefs. Nature 450 (7166): 98-101.

Munday, P.L. 2004. Habitat loss, resource specialization, and extinction on coral reefs. Global Change Biology 10 (10): 1642-1647.

Murphy, M.1., S.W. Johnson, and D.J. Csepp. 2000. A comparison of fish assemblages in eelgrass and adjacent subtidal habitats near Craig, Alaska. Alaska Fishery Research 7: 11-21.

Myers, R.A., and B. Worm. 2003. Rapid worldwide depletion of predatory fish communities. Nature 423 (6937): 280-283.

Myers, N., R.A. Mittermeler, C.G. Mittermeler, G.A.B. Da Fonseca, and J. Kent. 2000. Biodiversity hotspots for conservation priorities. Nature 403 (6772): 853-858.

Nagelkerken, I., M. Sheaves, R. Baker, and R.M. Connolly. 2015. The seascape nursery: a novel spatial approach to identify and manage nurseries for coastal marine fauna. Fish and Fisheries 16 (2): 362 371.

Nakamura, Y. 2010. Patterns in fish response to seagrass bed loss at the southern Ryukyu Islands, Japan. Marine Biology 157 (11): 2397 2406.

Nakamura, Y., and M. Tsuchiya. 2008. Spatial and temporal patterns of seagrass habitat use by fishes at the Ryukyu Islands, Japan. Estuarine, Coastal and Shelf Science 76 (2): 345-356.

Oksanen, J., F.G. Blanchet, M. Friendly, R. Kindt., P. Legendre, D. McGlinn, P.R. Minchin, R. B. O'Hara, G.L. Simpson, P. Solymos, M. Henry, M. Stevens, E. Szoecs, and H. Wagner. 2020. vegan: Community Ecology Package. Retrieved from https://cran.rproject.org/package=vegan. Accessed 1 Sept 2020.

O'Leary, J.K., F. Micheli, L. Airoldi, C. Boch, G. De Leo, R. Elahi, F. Ferretti, N.A.J. Graham, S.Y. Litvin, N.H. Low, S. Lummis, K.J. Nickols, J. Wong. 2017. The resilience of marine ecosystems to climatic disturbances. BioScience 67 (3):208-220.

Orth, R.J., T.J.B. Carruthers, W.C. Dennison, C.M. Duarte, J.W. Fourqurean, K.L. Heck, A.R. Hughes, G.A. Kendrick, W.J. Kenworthy, S. Olyarnik, F.T. Short, M. Waycott, and S.L. Williams. 2006. A global crisis for seagrass ecosystems. BioScience 56 (12): 987-996.

Pauly, D., V. Christensen, S. Guénette, T.J. Pitcher, U.R. Sumaila, C.J. Walters, R. Watson, and D. Zeller. 2002. Towards sustainability in world fisheries. Nature 418 (6898): 689-695.

Phelan, P.J., J. Steinbeck, and R.K. Walter. 2018. Influence of internal bores on larval fish abundance and community composition. Regional Studies in Marine Science 20: 1-12.

Pihl, L., S. Baden, N. Kautsky, P. Rönnbäck, T. Söderqvist, M. Troell, and H. Wennhage. 2006. Shift in fish assemblage structure due to loss of seagrass Zostera marina habitats in Sweden. Estuarine, Coastal and Shelf Science 67 (1-2): 123-132.
Pike, N. 2011. Using false discovery rates for multiple comparisons in ecology and evolution. Methods in Ecology and Evolution 2 (3): 278-282.

Pimm, S.L., C.N. Jenkins, R. Abell, T.M. Brooks, J.L. Gittleman, L.N. Joppa, P.H. Raven, C.M. Roberts, and J.O. Sexton. 2014. The biodiversity of species and their rates of extinction, distribution, and protection. Science 344 (6187): 1246752.

Pratchett, M.S., D.J. Coker, G.P. Jones, and P.L. Munday. 2012. Specialization in habitat use by coral reef damselfishes and their susceptibility to habitat loss. Ecology and Evolution 2 (9): 21682180.

R Core Team. 2020. R: a language and environment for statistical computing. Vienna, Austria: R Foundation for Statistical Computing.

Robblee, M.B., T.R. Barber, P.R. Carlson, M.J. Durako, J.W. Fourqurean, L.K. Muehlstein, D. Porter, L.A. Yarbro, R.T. Zieman, and J.C. Zieman. 1991. Mass mortality of the tropical seagrass Thalassia testudinum in Florida Bay (USA). Marine Ecology Progress Series 71: 297-299.

Rooper, C.N., D.R. Gunderson, and D.A. Armstrong. 2006. Evidence for resource partitioning and competition in nursery estuaries by juvenile flatfish in Oregon and Washington. Fishery Bulletin 104: 616622.

Scheffer, M., S. Carpenter, J.A. Foley, C. Folke, and B. Walker. 2001. Catastrophic shifts in ecosystems. Nature 413 (6856): 591-596.

Sherman, K., and L.A. Debruyckere. 2018. Eelgrass habitats on the U.S. West Coast: state of the knowledge of eelgrass ecosystem services and eelgrass extent. A publication prepared by the Pacific Marine and Estuarine Fish Habitat Partnership for The Nature Conservancy. $67 \mathrm{pp}$. https://montereybay.noaa.gov/research/techreports/ trsherman2018.html. Accessed 10 March 2020.

Short, F.T., and S. Wyllie-Echeverria. 1996. Natural and human-induced disturbance of seagrasses. Environmental Conservation 23 (1): 17 27.

Short, F., T. Carruthers, W. Dennison, and M. Waycott. 2007. Global seagrass distribution and diversity: a bioregional model. Journal of Experimental Marine Biology and Ecology 350 (1-2): 3-20.

Short, F.T., B. Polidoro, S.R. Livingstone, K.E. Carpenter, S. Bandeira, J.S. Bujang, H.P. Calumpong, T.J.B. Carruthers, R.G. Coles, W.C. Dennison, P.L.A. Erftemeijer, M.D. Fores, A.S. Freeman, T.G. Jagtap, A.H.M. Kamal, G.A. Kendrick, W.J. Kenworthy, Y.A. La Nafie, I.M. Nastution, R.J. Orth, A. Prathep, J.C. Sanciagco, B. van Tussenbroek, S.G. Vergara, M. Waycott, and J.C. Zeiman. 2011. Extinction risk assessment of the world's seagrass species. Biological Conservation 144 (7): 1961-1971.

Sobocinski, K.L., R.J. Orth, M.C. Fabrizio, and R.J. Latour. 2013. Historical comparison of fish community structure in lower Chesapeake Bay seagrass habitats. Estuaries and Coasts 36 (4): 775-794.

Stuart-Smith, R.D., C.J. Brown, D.M. Ceccarelli, and G.J. Edgar. 2018. Ecosystem restructuring along the Great Barrier Reef following mass coral bleaching. Nature 560 (7716): 92-96.

Underwood, A.J. 1995. Ecological research and (and research into) environmental management. Ecological Applications 5 (1): 232-247.

Vanderklift, M.A., and C.A. Jacoby. 2003. Patterns in fish assemblages 25 years after major seagrass loss. Marine Ecology Progress Series 247: $225-235$.

Venables, W.N., and B.D. Ripley. 2002. Modern Applied Statistics with S. Fourth. New York: Springer.

Walter, R.K., E.J. Rainville, and J.K. O'Leary. 2018a. Hydrodynamics in a shallow seasonally low-inflow estuary following eelgrass collapse. Estuarine, Coastal and Shelf Science 213: 160-175.

Walter, J.K., K.J. Armenta, B. Shearer, I. Robbins, and J. Steinbeck. 2018b. Coastal upwelling seasonality and variability of temperature and chlorophyll in a small coastal embayment. Continental Shelf Research 154: 9-18. 
Walter, R.K., J.K. O'Leary, S. Vitousek, M. Taherkhani, C. Geraghty, and A. Kitajima. 2020. Large-scale erosion driven by intertidal eelgrass loss in an estuarine environment. Estuarine, Coastal and Shelf Science 243 (2020): 106910

Wang, Z.B., D.S. Van Maren, P.X. Ding, S.L. Yang, B.C. Van Prooijen, P.L.M. DeVet, J.C. Winterwerp, H.J. DeVriend, M.J.F. Stive, and Q. He. 2015. Human impacts on mophodyanmic thresholds in estuarine systems. Continental Shelf Research 111: 174-183.

Wasserman, R.J., A.K. Whitfield, S.H.P. Deyzel, N.C. James, and S. Hugo. 2020. Seagrass (Zostera capensis) bed development as a predictor of size structured abundance for a ubiquitous estuarydependent marine fish species. Estuarine, Coastal and Shelf Science 238: 106694.

Waycott, M., C.M. Duarte, T.J.B. Carruthers, R.J. Orth, W.C. Dennison, S. Olyarnik, A. Calladine, J.W. Fourqurean, K.L. Heck Jr., A.R. Hughes, G.A. Kendrick, W.J. Kenworthy, F.T. Short, and S.L. Williams. 2009. Accelerating loss of seagrasses across the globe threatens coastal ecosystems. Proceedings of the National Academy of Sciences of the United States of America 106 (30): 12377-12381.

Whitfield, A.K. 2017. The role of seagrass meadows, mangrove forests, saltmarshes and reed beds as nursery areas and food sources for fishes in estuaries. Reviews in Fish Biology and Fisheries 27: 71110
Whitfield, A.K., N.C. James, P. Teske, T. Mkare, and P. Cowley. 2017. Life histories explain the conservation status of two estuaryassociated pipefishes. Biological Conservation 212: 256-264.

Wickham, H. 2009. ggplot2: Elegant Graphics for Data Analysis. New York: Springer-Verlag Retrieved from http://ggplot2.org. Accessed 1 Sept 2020.

Wiebe, J.P. 1968. The reproductive cycle of the viviparous seaperch, Cymatogaster aggregata Gibbons. Canadian Journal of Zoology 46 (6): 1221-1234.

Williams, G.D., and J.B. Zedler. 1999. Fish assemblage composition in constructed and natural tidal marshes of San Diego Bay: relative influence of channel morphology and restoration history. Estuaries 22 (3): 702.

Wilson, AB. 2006. Genetic signature of recent glaciation on populations of a near-shore marine fish species (Syngnathus leptorhynchus). Molecular Ecology 15: 1857-1871.

Yeager, L.A., D.A. Keller, T.R. Burns, A.S. Pool, and F.J. Fodrie. 2016. Threshold effects of habitat fragmentation on fish diversity at landscapes scales. Ecology 97 (8): 2157-2166.

Yoklavich, M.M., G.M. Cailliet, J.P. Barry, D.A. Ambrose, and B.S. Antrim. 1991. Temporal and spatial patterns in abundance and diversity of fish assemblages in Elkhorn Slough, California. Estuaries 14 (4): 465-480. 